\title{
Triple Antithrombotic Therapy in Patients with Acute Coronary Syndrome and Atrial Fibrillation - Balancing Risks and Benefits
}

\author{
Alexandru DEACONU ${ }^{1}, 2$, Silvia DEACONU ${ }^{1}, 2$, Andreea GATEJ ${ }^{1}$, Maria DOROBANTU1 2
}

\begin{abstract}
Backround: Optimal antithrombotic therapy in patients with AF who undergo coronary stenting for an ACS has been a subject of constant change, with the addition of numerous trials in recent years. Objectives: The aim of our study was to assess current antithrombotic treatment in patients with AF and ACS treated with PCl. Material and methods: We performed a observational retrospective study on patients with nonvalvular AF, ACS and PCI between January 2017 and May 2019. We assessed both ischemic risk (IR) and haemorrhagic risk (HR) according to the 2018 ESC guidelines strategies. Results: 184 patients with nonvalvular AF and ACS treated with PCI were eligible for inclusion. In the whole cohort the HR was significantly higher than the IR (3.66+/-1.15 respectively $2.84+/$ $1.15, p<0.001)$. NSTEMI carries both the highest IR and HR $(p<0.05)$. The majority of patients $(88.04 \%)$ received triple antithrombotic therapy mostly for one month (39\%). Main drug combination used was Aspirin, Clopidogrel, antivitamin $\mathrm{K}(48.48 \%)$. Conclusions: In our registry of AF patients with ACS treated with $\mathrm{PCl}$, triple antithrombotic therapy is still the strategy of choice with an initial duration of one month. In our cohort, HR is higher than IR, NSTEMI carrying the highest risks out of all the ACS.
\end{abstract}

Keywords: atrial fibrillation, acute coronary syndrome, antithrombotic therapy, ischaemic risk, haemorrhagic risk.

\section{Rezumat}

Context: Terapia optimală antitrombotică a pacienților cu fibrilație atrială (AF), care în urma unui sindrom coronarian acut (ACS) sunt tratați prin angioplastie cu implantare de stent (PCI) este un subiect aflat în continuă modificare, dovada fiind numeroasele studii realizate în ultimii ani. Obiective: Scopul studiului nostru a fost să evaluăm terapia curentă antitrombotică a pacienților cu AF și ACS tratați prin PCI. Material și metodă: Am inclus în acest studiu retrospectiv pacienții cu AF non-valvulară, ACS și PCl în perioada dintre ianuarie 2017 și mai 2019. Am analizat atât riscul ischemic cât și cel hemoragic în concordanță cu strategiile ghidurilor Societății Europene de Cardiologie (ESC) din 2018. Rezultate: 184 de pacienți cu AF non-valvulară și ACS tratat prin $\mathrm{PCl}$ au îndeplinit criteriile de includere. Pentru cohorta studiată, riscul hemoragic (HR) a fost semnificativ statistic mai mare decât riscul ischemic (IR) $(3.66+/-1.15$, respectiv IR 2.84+/-1.15, p < 0.001). Ambele riscuri domină în cazul ACS de tip NSTEMI $(p<0.05)$. Majoritatea pacienților (88.04\%) au primit triplă terapie antitrombotică timp de o lună (39\%). Principala combinație de agenți farmacologici a fost Aspirina, Clopidogrel și anticoagulare cu antivitamină K (48.48\%). Concluzii: În cadrul registrului nostru de AF, pacienții cu ACS tratați prin $\mathrm{PCl}$ au primit tripla terapie antitrombotică de primă intenție, cu prescriere inițială timp de o lună. Pentru cohorta studiată HR depășește IR, iar la pacienții cu NSTEMI riscurile cercetate domină în comparație cu celelalte tipuri de ACS.

Cuvinte cheie: fibrilație atrială, sindrom coronarian acut, terapie antitrombotică, risc ischemic, risc hemoragic.

${ }^{1}$ "Carol Davila" University of Medicine and Pharmacy, Bucharest, Romania

${ }^{2}$ Department of Cardiology, Emergency Clinical Hospital,

Bucharest, Romania
Corresponding author:

Alexandru DEACONU, Department of Cardiology, Emergency

Clinical Hospital, Bucharest, Romania.

E-mail: alexandru_deaconu@yahoo.com 


\section{INTRODUCTION}

The association between nonvalvular atrial fibrillation (AF) and acute coronary syndrome (ACS) undergoing percutaneous coronary intervention (PCI) brings together a challenging therapeutical approach both in acute setting and long-term. Optimizing treatment for these patients in accordance with the ischaemic and bleeding risk balance remains a difficult decision to take. Until recently the attention pointed mostly towards lowering the thrombotic risk and less towards the possible haemorrhagic complication. The latest guidelines, however, encourage a more balanced approach with triple therapy being reserved only for high ischaemic risk patients ${ }^{1}$.

\section{Objectives}

The aim of our study was to assess the current antithrombotic treatment for patients with $\mathrm{AF}$ and ACS after PCI. Based on the ESC guidelines for myocardial revascularization (2018) that introduce the calculation of haemorrhagic risk (HR) and ischaemic risk (IR) (Table 1,2), we sought to analyse in real life the relation between these risks and the treatment recommended ${ }^{2}$.

\section{MATERIALS AND METHODS}

We performed a observational retrospective study including 184 patients with nonvalvular AF, ACS and PCI between January 2017 and May 2019, admitted in the Emergency Clinical Hospital of Bucharest.
Inclusion criteria were defined by presence of nonvalvular AF (either treated with oral anticoagulants [OAC] until time of integration in the study or not), associating ACS for which they underwent PCI with drug-eluted stent (DES) or bare metal stent (BMS).

Exclusion criteria consisted of presence of prosthetic heart valve implantation (metallic or biological). severe chronic renal disease (DOACs treatment being contraindicated in this case), recent major bleeding such as haemorrhagic stroke or surgery.

Data was collected in terms of AF types (permanent, paroxysmal and persistent), ACS types (ST-segment elevation myocardial infarction [STEMI], non-STelevation myocardial infarction [NSTEMI] or unstable angina [UA]), glomerular filtration rate (GFR), treatment at discharge, duration of initial treatment.

We assessed both ischaemic risk (IR) and haemorrhagic risk (HR) according to 2018 ESC guideline strategies" ${ }^{20}$ - Table 1, Table 2 .

Definition of treatment:

1. Dual antithrombotic treatment (DAP) is defined by combination of an antiplatelet agent such as Aspirin (A) or $\mathrm{P}_{2} \mathrm{Y}_{12}$ inhibitor $\left(\mathrm{P}_{2} \mathrm{Y}_{12}\right)$ and an oral anticoagulant (VKA or DOACs).

2. Dual antiplatelet treatment (DAPT) represents the combination of two antiplatelet drugs (A and $\mathrm{P} 2 \mathrm{Y}_{12}$ - mostly Clopidogrel).

3. Triple antithrombotic treatment (TAT) consists of association between two antiplatelet drugs (A and $\mathrm{P}_{2} \mathrm{Y}_{12}$ - usually Clopidogrel) and an oral anticoagulant (VKA or DOACs).

Table 1. Ischaemic risk calculation

\begin{tabular}{|l|l|}
\hline Variable & \multicolumn{2}{l|}{ Points } \\
\hline Prior stent thrombosis on adequate antiplatelet therapy & \multicolumn{1}{|c|}{1} \\
\hline Stenting of the last remaining patent coronary artery & 1 \\
\hline Diffuse multivessel disease, especially in diabetic patients & 1 \\
\hline Chronic kidney disease (i.e. creatinine clearance $<60 \mathrm{~mL} / \mathrm{min})$ & 1 \\
\hline At least three stents implanted & 1 \\
\hline At least three lesions treated & 1 \\
\hline Bifurcation with two stents implanted & 1 \\
\hline Total stented length $>60$ mm & 1 \\
\hline Treatment of a chronic total occlusion & 1 \\
\hline History of STEMI & 1 \\
\hline
\end{tabular}


Table 2. Haemorrhagic risk calculation

\begin{tabular}{|l|l|}
\hline Variable & Points \\
\hline Short life expectancy & 1 \\
\hline Ongoing malignancy & 1 \\
\hline Poor expected adherence & 1 \\
\hline Poor mental status & 1 \\
\hline End-stage renal failure & 1 \\
\hline Advanced age & 1 \\
\hline Prior major bleeding/prior haemorrhagic stroke & 1 \\
\hline Chronic alcohol abuse & 1 \\
\hline Anaemia & 1 \\
\hline Clinically significant bleeding on dual antithrombotic therapy & 1 \\
\hline
\end{tabular}

Table 3. Summary of characteristics among the whole cohort and different types of ACS; TAT = triple antithrombotic therapy; $\mathrm{DAT}=$ double antithrombotic therapy; DAPT = double antiplatelet therapy

\begin{tabular}{|c|c|c|c|c|c|}
\hline Variables & $\begin{array}{l}\text { Overall } \\
(n=184)\end{array}$ & $\begin{array}{l}\text { STEMI } \\
(n=113)\end{array}$ & $\begin{array}{l}\text { NSTEMI } \\
(\mathbf{n}=\mathbf{2 1})\end{array}$ & $\begin{array}{l}\text { UA } \\
(n=50)\end{array}$ & p value \\
\hline Age & $73.48+/-9,75$ & $72.84+/-10.24$ & $77.8+/-9.6$ & $73.12+/-9.75$ & 0.09 \\
\hline Male (\%) & 67.39 & 67.26 & 61.90 & 70 & 0.8 \\
\hline $\operatorname{GFR}(\mathrm{ml} / \mathrm{min})$ & $66.57+/-22.49$ & $67.47+/-21.92$ & $66.74+/-23.6$ & $64.47+/-22.49$ & \\
\hline Ischaemic risk & $2.84+/-1.15$ & $2.57+/-0.96$ & $3.38+/-1.68$ & $3.22+/-1.11$ & 0.002 \\
\hline Haemorrhagic risk & $3.66+/-1.15$ & $3.5+/-1.16$ & $4.1+/-1.3$ & $3.8+/-0.98$ & 0.03 \\
\hline $\begin{array}{l}\text { Antithrombotic therapy } \\
\text { TAT } \\
\text { DAT } \\
\text { DAPT }\end{array}$ & $\begin{array}{l}88.04 \\
3.80 \\
8.15\end{array}$ & $\begin{array}{l}86.73 \\
2.00 \\
8.85\end{array}$ & $\begin{array}{l}80.95 \\
4.76 \\
14.29\end{array}$ & $\begin{array}{l}94.00 \\
2.00 \\
4.00\end{array}$ & 0.5 \\
\hline $\begin{array}{l}\text { First medication stopped } \\
\text { Unspecified } \\
\text { Aspirin } \\
\text { Clopidogrel } \\
\text { Anticoagulant }\end{array}$ & $\begin{array}{l}57.41 \\
20.99 \\
19.75 \\
1.85\end{array}$ & $\begin{array}{l}57.14 \\
20.41 \\
20.41 \\
2.04\end{array}$ & $\begin{array}{l}58.82 \\
5.88 \\
29.41 \\
5.88\end{array}$ & $\begin{array}{l}57.45 \\
27.66 \\
14.89 \\
0\end{array}$ & 0.3 \\
\hline $\begin{array}{l}\text { Atrial fibrillation } \\
\text { Permanent } \\
\text { Persistent } \\
\text { Paroxysmal }\end{array}$ & $\begin{array}{l}26.63 \\
22.83 \\
50.54\end{array}$ & $\begin{array}{l}20.35 \\
20.35 \\
59.29\end{array}$ & $\begin{array}{l}50.38 \\
23.81 \\
23.81\end{array}$ & $\begin{array}{l}30.00 \\
28.00 \\
42.00\end{array}$ & $\mathrm{P}=0.009$ \\
\hline
\end{tabular}


Patient data was collected using the hospital informational system and it was processed separately.

Statistical analysis

Results were expressed as mean \pm standard deviation for continuous variables and percentage for categorical variables. Differences between continuous variables were analysed with independent $t$ test. One way ANOVA was used to asess differences of $\mathrm{HR}$ and IR, age, GFR among SCA types. Categorical variables were compared with chi-square test. $\mathrm{p}$ value $<0.05$ was considered statistical significant. All analyses and graphs were performed using STATA Statistical Software (StataCorp, College Station, TX, USA; version 16 for macOS).

\section{RESULTS}

184 patients with nonvalvular AF and ACS treated with PCI were eligible for inclusion. Table 3 summarizes the main characteristics of our cohort and according to types of ACS.

In the whole cohort the HR was significantly higher than the IR 3.66+/-1.15, respectively IR $2.84+/-1.15$ $(\mathrm{p}<0.001)$. HR is significantly higher than IR in STEMI and UA $(\mathrm{p}<0.001$ respectively $\mathrm{p}=0.005)$ but not among NTEMI patients $(\mathrm{p}=0.11)$-Table 3 .

Among ACS types there are significant differences concerning $\mathrm{HR}$ and IR. Both $\mathrm{HR}$ and IR differ significantly with a higher value in NSTEMI patients followed by UA, and then STEMI $(\mathrm{F}(2,181)=8.7$, $\mathrm{p}$ $<0.001$ for HR, $\mathrm{F}(2,181)=3.44, \mathrm{p}=0.03$ for IR among ACS types) - Figure 1.

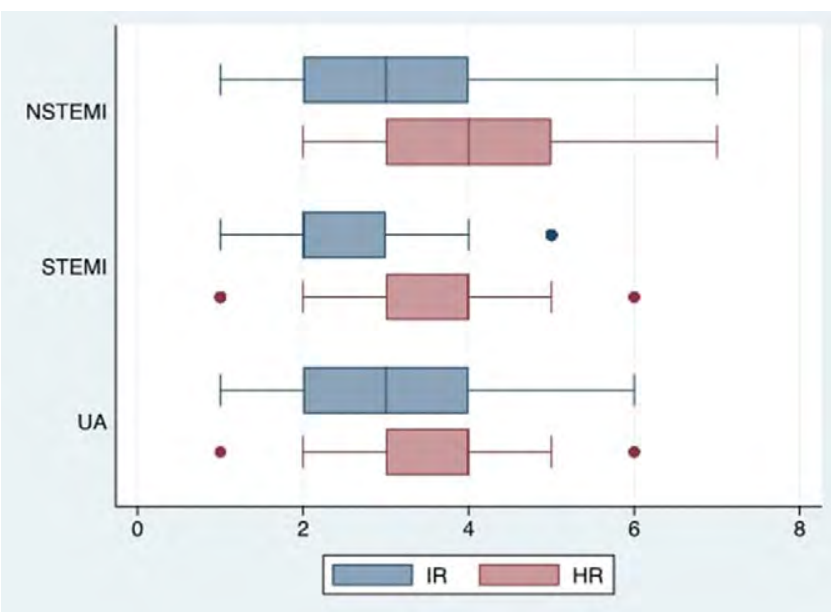

Figure 1. Compared ischaemic and bleeding risk according to type of acute coronary syndrome (ACS); IR = ischaemic risk; $\mathrm{HR}=$ haemorrhagic risk
The primary category of AF was paroxysmal $50.54 \%$ (table 3). Interestingly, there was a significant difference between ACS types, with the predominance of permanent AF in NSTEMI patients compared to STEMI and UA where paroxysmal AF is most frequent $(\mathrm{p}<0.05)$.

In spite of greater HR in all the ACS categories, the main treatment recommendation was TAT (Table 3 , Figure 2).

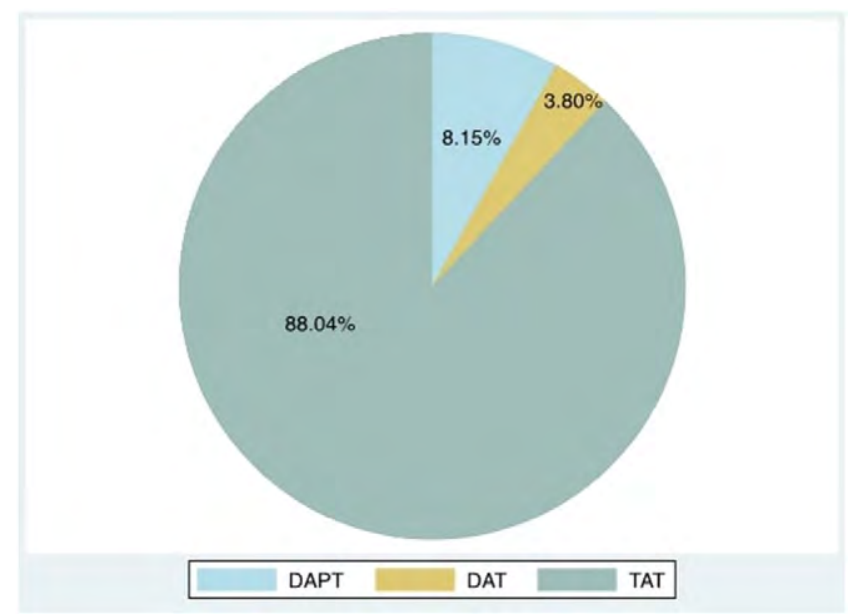

Figure 2. Percentage distribution of the antithrombotic therapeutical strategies; TAT $=$ triple antithrombotic therapy; $\mathrm{DAT}=$ double antithrombotic therapy; DAPT = double antiplatelet therapy

When looking at the duration of treatment initiated most of the patients had been recommended to maintain the first scheme for one month (39\%) Figure 3, Figure 4.

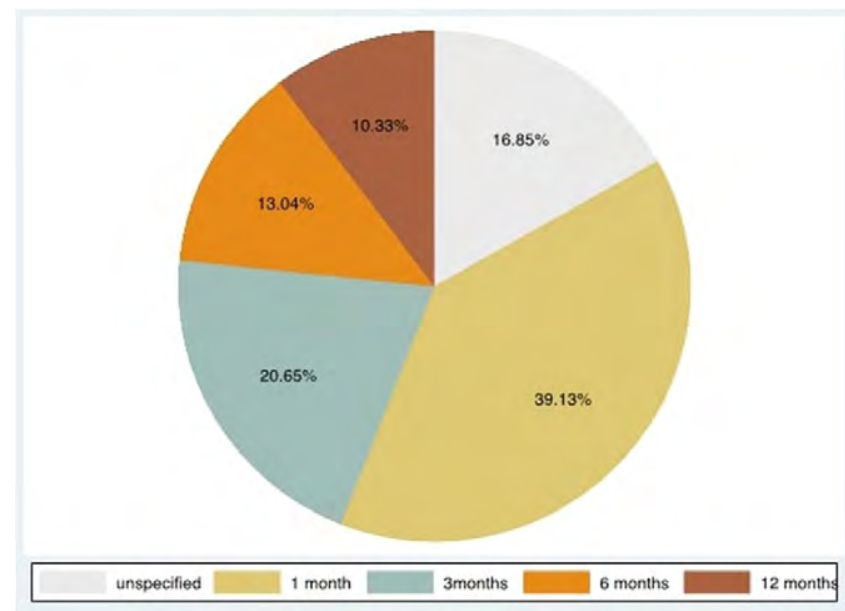

Figure 3. Duration of recommended triple antithrombotic therapy (TAT) 
Table 4. Outline of medication schemes recommended at discharge of patients. AVK = antivitamin $\mathrm{K}$ anticoagulants

\begin{tabular}{|l|c|c|}
\hline Therapy & Percent (\%) & Number of patients \\
\hline Aspirin, Clopidogrel, AVK & 43.48 & 80 \\
\hline Aspirin, Clopidogrel, Apixaban 2,5mg & 18.48 & 34 \\
\hline Aspirin, Clopidogrel, Apixaban 5mg & 13.04 & 24 \\
\hline Aspirin, Clopidogrel, Dabigatran 110mg & 5,98 & 11 \\
\hline Aspirin, Clopidogrel & 4.8 & 9 \\
\hline Aspirin, Clopidogrel, Rivaroxaban 15mg & 4.35 & 8 \\
\hline Aspirin, Ticagrelor & 3.2 & 6 \\
\hline Aspirin, Ticagrelor, AVK & 1.63 & 3 \\
\hline Clopidogrel, AVK & 1.63 & 3 \\
\hline Other & 2.16 & 4 \\
\hline
\end{tabular}

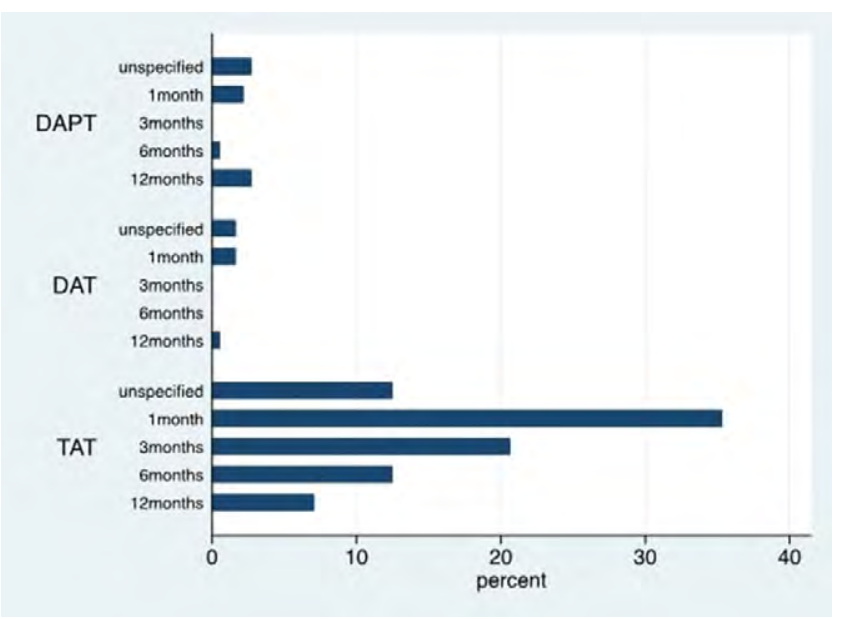

Figure 4. Percentage distribution of time recommendations for each antithrombotic strategy; TAT=triple antithrombotic therapy; DAT = double antithrombotic therapy; DAPT = double antiplatelet therapy

\section{DISCUSSIONS}

The major conclusions of our study are that:

1. HR is higher than IR in our cohort of patients with $\mathrm{AF}$ and $\mathrm{SCA}$ requiring $\mathrm{PCI}$

2. NSTEMI patients carry the highest HR and IR among SCA types

3. Main recommended treatment was TAT with an initial duration of one month

4. Main recommended medication was: Aspirin, Clopidogrel, AVK

Optimal antithrombotic therapy in patients with AF who undergo coronary stenting for an ACS has been a subject of constant change, with the addition of numerous trials in recent years. In the 2015 ESC guidelines, 6 months of TAT, followed by up to 12 months of DAT was the recommended approach for low bleeding risk. For a high bleeding risk, TAT had to be continued for 1 month, followed by up to 12 months of $\mathrm{DAT}^{3}$. In the 2018 ESC guidelines, a more comparative management regarding both risks (ischaemic and haemorrhagic) was presented. In patients with a dominant ischaemic risk, 1 month of TAT with possible extent to up to 6 months, then up to 12 months of DAT. A dominant bleeding risk adjustated the TAT to only 4 weeks, with the alternative of choosing DAT instead from the very beginning up to 12 months. In addition, guidelines advised the use of DOACs over the VKA ${ }^{2}$. Four major randomized controlled trials (RCTs) (Pioneer AFPCI, RE-DUAL AF-PCI, ENTRUST AF-PCI and AUGUSTUS AF-PCI) stated that DAT using the currently available direct oral anticoagulants (DOACs) (Rivaroxaban, Dabigatran, Edoxaban, respectively Apixaban) is associated with reduced bleeding risk, compared to TAT based on vitamin $\mathrm{K}$ antagonists (VKA) therapy ${ }^{4-7}$.

Based on these trials, clearer guidance was provided in the latest $2020 \mathrm{ESC}$ guidelines on AF, emphasizing the less-is-more concept and the assumption that there is no one size to fit all. Early cessation of TAT is encouraged, limiting its usage to $\leq 1$ week. Surpassing the 1-week threshold of TAT should only be done in certain cases where ischaemic risk is prevalent, but even so it should not be conducted for more than 4 weeks ${ }^{1}$. 
In our cohort, the main treatment recommended was TAT for 1 month. This strategy was according to the guidelines of that period of time. Interestingly, when we analysed the HR and IR we discovered that the HR overcomes IR in the whole cohort of ACS patients with PCI and in STEMI and UA patients. Only in NSTEMI there was not a statistically significant difference between HR and IR.

On the other hand, NSTEMI carries also the highest HR and IR compared to STEMI and UA. Other studies reveal an increased overall bleeding risk in the NSTEMI patients category ${ }^{8}$. This data underlines the complexity of NSTEMI patients who usually associate multiple comorbidities 9 .

In our cohort, DAT was administered in a very low number of patients $(3,8 \%)$, even lower than DAPT alone (8.15\%). In a study conducted by De Luca et al in similar patients the treatment had the same distribution with predominance of TAT, followed by DAPT and DAT $(64.8 \%, 25.7 \%$ respectively $8.8 \%)^{10}$. We hypothesize that there are numerous explanations for this phenomenon. Firstly, in 2017, a more conservative approach was recommended, the new trials and guidelines encouraging a shorter TAT coming into practice in the period 2017-2019. Secondly, cardiologists tend to encounter more frequently in their practice thrombotic complications rather than haemorrhagic side-effects of aggressive treatment, thus feeling more comfortable with minimizing the ischaemic risk of their patients.

In our cohort, most of the patients associated paroxysmal AF (50.54\%). STEMI and UA associated paroxysmal AF unlike NSTEMI which associated permanent AF. Presence of permanent AF in NSTEMI may reflect the more advanced heart disease ${ }^{11}$. Most of the patients were recommended Aspirin, Clopidogrel and AVK (48.8\%) followed at distance by administration of Apixaban low dose and full dose. The preference for VKA over DOAC in our cohort may also be determined by economic reasons, since at that time DOACs were not covered by public insurance.
The duration of initial treatment was mostly for one month, with recommendation of stopping Aspirin or Clopidogrel (20.99 vs 19.75\%) followed by DAT.

There are several randomised controlled trials assessing the safety of replacing TAT with DAT in patients with AF treated with PCI which showed that DAT is associated with reduced risk for major bleeding compared with TAT ${ }^{12-14}$.

TAT is associated with a high rate of major and fatal bleeding events ${ }^{15}$. On the other hand, there are studies showing an increased early stent thrombosis with DAT as compared with TAT with DOACs ${ }^{16}$. These findings support a short initial course of TAT in all patients with $\mathrm{ACS}$ with $\mathrm{AF}^{17}$. Consequently, the choice between DAT and TAT should be made on a case-to-case basis, taking into consideration both the bleeding as well as ischaemic risks.

\section{CONCLUSIONS}

Although recent studies showed the safety of DAT in patients with $\mathrm{AF}$ who underwent coronary stenting for an ACS, our data demonstrate that TAT is still largely prescribed. Initial duration of TAT was most frequently one month. Most of our patients carry a HR that outweighs the IR, thus a 'less is more' strategy seems beneficial.

\section{STUDY LIMITATIONS}

Single center experience, considerable differences in numbers among the subgroups of STEMI, UA and NSTEMI. The presented study lacks follow-up, but this is currently on-going and will be presented in the future.

Compliance with ethics requirements: The authors declare no conflict of interest regarding this article. The authors declare that all the procedures and experiments of this study respect the ethical standards in the Helsinki Declaration of 1975, as revised in 2008(5), as well as the national law. Informed consent was obtained from all the patients included in the study. 


\section{References}

1 G. Hindricks et al., "2020 ESC Guidelines for the diagnosis and management of atrial fibrillation developed in collaboration with the European Association for Cardio-Thoracic Surgery (EACTS)," Eur. Heart J., vol. 42, no. 5, pp. 373-498, 2021, doi: 10.1093/ eurheartj/ehaa612.

2 F. J. Neumann et al., "2018 ESC/EACTS Guidelines on myocardial revascularization," European Heart Journal, vol. 40, no. 2. Oxford University Press, pp. 87-165, Jan. 07, 2019, doi: 10.1093/ eurheartj/ehy394.

3 M. Roffi et al., "2015 ESC Guidelines for the management of acute coronary syndromes in patients presenting without persistent st-segment elevation: Task force for the management of acute coronary syndromes in patients presenting without persistent ST-segment elevation of ," European Heart Journal, vol. 37, no. 3. Oxford University Press, pp. 267-315, Jan. 01, 2016, doi: 10.1093/eurheartj/ehv320.

4 C. P. Cannon et al., "Dual Antithrombotic Therapy with Dabigatran after PCl in Atrial Fibrillation," N. Engl. J. Med., vol. 377, no. 16, pp. 1513-1524, Oct. 2017, doi: 10.1056/NEJMoa1708454.

5 R. D. Lopes et al., "Antithrombotic Therapy after Acute Coronary Syndrome or PCl in Atrial Fibrillation," N. Engl. J. Med., vol. 380, no. 16, pp. 1509-1524, Apr. 2019, doi: 10.1056/NEJMoa1817083.

6 P. Vranckx et al., "Edoxaban-based versus vitamin $\mathrm{K}$ antagonistbased antithrombotic regimen after successful coronary stenting in patients with atrial fibrillation (ENTRUST-AF PCI): a randomised, open-label, phase 3b trial," Lancet, vol. 394, no. 10206, pp. 13351343, Oct. 2019, doi: 10.1016/S0140-6736(19)31872-0.

7 C. M. Gibson et al., "Prevention of Bleeding in Patients with Atrial Fibrillation Undergoing PCl," N. Engl. J. Med., vol. 375, no. 25, pp. 2423-2434, Dec. 2016, doi: 10.1056/NEJMoa1611594.

8 A. Ariza-Solé et al., "CRUSADE bleeding risk score validation for ST-segment-elevation myocardial infarction undergoing primary percutaneous coronary intervention," Thromb. Res., vol. 132, no. 6, pp. 652-658, Dec. 2013, doi: 10.1016/j.thromres.2013.09.019.

$9 \mathrm{H}$. Y. Chen et al., "The impact of cardiac and noncardiac comorbidities on the short-term outcomes of patients hospitalized with acute myocardial infarction: A populationbased perspective," Clin. Epidemiol., vol. 5, no. 1, pp. 439-448, Nov. 2013, doi: 10.2147/CLEP.S49485.

10 L. De Luca et al., "Antithrombotic management of patients with acute coronary syndrome and atrial fibrillation undergoing coronary stenting: A prospective, observational, nationwide study," BMJ Open, vol. 10, no. 12, pp. 1-8, 2020, doi: 10.1136/ bmjopen-2020-041044.
11 R. Ofori-Asenso et al., "Prevalence and impact of noncardiovascular comorbidities among older adults hospitalized for non-ST segment elevation acute coronary syndrome," Cardiovasc. Diagn. Ther., vol. 9, no. 3, pp. 250-261, 2019, doi: 10.21037/cdt.2019.04.06.

12 D. Capodanno et al., "Management of Antithrombotic Therapy in Atrial Fibrillation Patients Undergoing PCI: JACC State-of-theArt Review," Journal of the American College of Cardiology, vol. 74, no. 1. Elsevier USA, pp. 83-99, Jul. 09, 2019, doi: 10.1016/j. jacc.2019.05.016.

13 S. U. Khan et al., "Dual versus triple therapy for atrial fibrillation after percutaneous coronary intervention a systematic review and meta-analysis," Annals of Internal Medicine, vol. 172, no. 7. American College of Physicians, pp. 474-483, Apr. 07, 2020, doi: 10.7326/M19-3763.

14 R. D. Lopes et al., "Optimal Antithrombotic Regimens for Patients with Atrial Fibrillation Undergoing Percutaneous Coronary Intervention: An Updated Network Meta-analysis," JAMA Cardiol., vol. 5, no. 5, pp. 582-589, May 2020, doi: 10.1001/ jamacardio.2019.6175

15 N. van Rein, U. Heide-Jørgensen, W. M. Lijfering, O. M. Dekkers, H. T. Sørensen, and S. C. Cannegieter, "Major bleeding rates in atrial fibrillation patients on single, dual, or triple antithrombotic therapy," Circulation, vol. 139, no. 6, pp. 775-786, Feb. 2019, doi: 10.1161/CIRCULATIONAHA.118.036248.

16 G. Gargiulo et al., "Safety and efficacy outcomes of double vs. triple antithrombotic therapy in patients with atrial fibrillation following percutaneous coronary intervention: A systematic review and meta-analysis of non-Vitamin $\mathrm{K}$ antagonist oral anticoagulant-based randomized clinical trials," Eur. Heart J., vol. 40, no. 46, pp. 3757-3767, Dec. 2019, doi: 10.1093/eurheartj/ ehz732.

17 J. H. Alexander et al., "Risk/Benefit Tradeoff of Antithrombotic Therapy in Patients with Atrial Fibrillation Early and Late after an Acute Coronary Syndrome or Percutaneous Coronary Intervention: Insights from AUGUSTUS," Circulation, vol. 141, no. 20, pp. 16181627, 2020, doi: 10.1161/CIRCULATIONAHA.120.046534. 